\title{
Sustainable Household Organic Waste Management via Vermicomposting
}

\author{
Fauziah S.H. ${ }^{1 *}$ and Agamuthu, $\mathbf{P}^{1}$. \\ ${ }^{1}$ Institute of Biological Sciences, Faculty of Science, University of Malaya, 50603 Kuala Lumpur, Malaysia \\ *fauziahsh@um.edu.my (Corresponding author) \\ Received in $23^{\text {rd }}$ September 2008, accepted in revised form $14^{\text {th }}$ July 2009.
}

\begin{abstract}
Increasing waste generation in developing countries has alarmed authorities on waste disposal issues. Therefore, various alternatives have been looked into to reduce waste disposed into landfill. Among others are the bioremediation options which may allow the conversion of putrescible wastes into value added products such as compost, biogas and others. This study was aimed to find optimal experimental set-up to conduct small scale vermicomposting suitable for households, since approximately $40-50 \%$ (wt) of the waste is putrescible component. The wastes were weighed and exposed to worms namely Eisenia foetida. Results indicated that household putrescible waste can easily undergo vermicomposting. However, factors such as high acidity and presence of certain materials in the waste can be detrimental to this process. Worms are very sensitive to $\mathrm{pH}$ changes and the vermicomposting process will reduce drastically when $\mathrm{pH}$ is lower than 5.0. Experimental set-up with the layering system proved to be the best method of conducting small scale vermicomposting. The layering set-up prevents worms from escaping the vermicomposting system and allows the gathering of the offspring in a safe environment. Different combinations of organic mixture resulted with different rate of vermicomposting completion. The fastest to degrade was the combination of kitchen waste with vermicompost, which come to completion within three weeks. Vermicompost provides the most suitable environment for the worms to flourish in addition to the availability of less complex components in kitchen waste. The average water holding capacity of the vermicompost was $25 \%$ (wt) while the total organic content was $12 \%$. In conclusion, vermicomposting of organic components found in the MSW stream can be accomplished by taking into consideration crucial factors such as acidity and presence of hindering components. The identification of the most suitable conditions for vermicomposting will allow the implementation of this alternative biological remedy to reduce waste and tackle the problem in waste management, particularly in developing countries.
\end{abstract}

\begin{abstract}
ABSTRAK Pertambahan penghasilan sisa di negara-negara membangun membimbangkan pihak berkuasa. Maka, pelbagai alternatif telah dipertimbangkan untuk mengurangkan jumlah sisa ke tapak pelupusan. Antara pilihan yang ada ialah bioremediasi yang membolehkan pertukaran sisa yang mudah terurai kepada produk bernilai seperti kompos, biogas dan lain-lain. Kajian ini bertujuan untuk mengetahui penyediaan eksperimen terbaik bagi menjalankan proses vermi-pengkomposan skala kecil yang sesuai bagi isirumah memandangkan hampir 40-50\% (berat) sisa yang dihasilkan terdiri daripada bahan mudah terurai. Sisa ditimbang dan didedahkan kepada cacing jenis Eisenia foetida. Keputusan menunjukkan bahawa sisa mudah terurai yang dihasilkan sesuai menjalani proses vermi-pengkomposan. Walau bagaimanapun, faktorfaktor seperti keasidan yang tinggi dan kehadiran elemen-elemen tertentu di dalam sisa boleh membantutkan proses ini. Cacing-cacing ini sensitif kepada perubahan $\mathrm{pH}$ dan proses vermi-pengkomposan akan menurun dengan drastik apabila $\mathrm{pH}$ kurang dari 5.0. Persediaan eksperimen dengan sistem lapisan terbukti sebagai teknik terbaik bagi menjalankan vermi-pengkomposan skala kecil. Sistem lapisan menghalang cacing keluar dari sistem vermi-pengkomposan dan membolehkan penggumpulan anak-anak cacing dalam persekitaran yang selamat. Kombinasi-kombinasi yang berbeza dalam campuran organik lengkap diproses pada kadar yang berbeza. Campuran sisa dapur dan vermi-kompos paling cepat terurai iaitu selepas tiga minggu. Ini adalah kerana ia menyediakan persekitaran yang paling sesuai bagi cacing untuk membiak di samping terdapatnya komponen-komponen yang kurang kompleks. Secara purata kapasiti air tanah bagi vermi-kompos ialah 25\% sementara kandungan organik total ialah $12 \%$. Sebagai kesimpulan, vermi-pengkomposan komponen organik dalam sisa munisipal boleh dijalankan dengan mengambil kira beberapa faktor penting seperti asiditi dan
\end{abstract}


kehadiran komponen penghalang tertentu. Pengenalpastian keadaan yang paling sesuai bagi vermipengkomposan membolehkan perlaksanaan rawatan biologi alternatif ini untuk mengurangkan sisa dan menyelesaikan masalah pengurusan sisa terutama di negara-negara membangun.

(Keywords: vermicomposting, kitchen waste, sustainable development)

\section{INTRODUCTION}

Population expansion resulted with rapid increase in waste generation. It is the effect of improved standard of living and improved health quality [1, 2]. Proper waste management is very crucial and has become the main challenge in many countries particularly the developing nations [3]. Malaysia with 3\% (wt) annual municipal solid waste (MSW) increase generates approximately 30,000 tonnes of MSW covering $83 \%$ of the country's waste generation. Less than $5 \%$ of the waste is diverted by unofficial recycling activities while the remaining $95 \%$ goes to the landfill for disposal [4]. The disposal of the ever increasing waste requires approximately RM1 billion (US\$26 million) and it is expected to increase with the increase in the price of fuel [5]. In addition, the huge tonnage of waste disposed into landfills resulted with various environmental impacts including leachate contamination, pest problem and others. To make matter worse, approximately $90 \%$ of the country's non sanitary landfills lacked geotextile lining material to prevent groundwater contamination. This has called for an urgent need for various alternatives to divert waste from landfill. This not only lengthens the operational period of a landfill but also would reduce the risk of environmental degradation.

Putrescible wastes can be converted into value added products such as compost, biogas and others $[6,7,8,9]$. The most common and widely practiced bioremediation technique is composting. Composting product i.e. compost consist of necessary minerals which act as organic fertilizer to enhance plant growth and improve soil condition [10, 11]. Countries like Austria and Denmark had implemented the requirement of organic waste composting as an alternative to reduce waste for landfill disposal [12, 13]. Temperature, moisture content, nutrient content, $\mathrm{pH}$, particle size, and oxygen supply are among the factors that will determine the quality of the compost [14]. Various organisms are involved in the composting process which includes microorganism like bacteria, fungi and worms. However, commercial composting is only viable if it is conducted at a large scale. Smaller scale composting particularly in individual households would require various additives and complex compost set-up to prevent offensive odour from degrading waste and to curb pest problem. The application which is more suitable for individual household is vermicomposting since the uncomfortable smell is very minimal and it generates very high quality compost [15].

Various species of worm have been used to digest and break down the organic matters during vermicomposting. It includes Eisenia foetida, Lumricus rubellus, Perionyx excavatus, Lampito mauritii, Eudrilus euginea, and Pheretima elongate [15, 16, 17]. Eisenia foetida is more adaptable to tropical condition to convert waste into vermicompost with various benefits including extra advantages on pest control in soil $[15,18]$. Vermicomposting can be carried-out in a smaller scale that it is more applicable to individual household to treat kitchen and garden wastes since approximately $40-50 \%$ (wt) of the waste is putrescible. With appropriate yet simple set-up, individual household would be able to carry out vermicomposting which would eventually reduce at least 35\% the total waste generation per household. Suitable set-up would ensure the viability of the vermicomposting system which would continuously receive the putrescible component of the domestic waste. Though many publications had discussed the process of vermicomposting and the factors involved, they focused mainly on large scale vermicomposting. Studies on the feasibility of household scale vermicomposting are lacking. Disposal of waste 
directly into landfill is not environmental friendly. This not only pollutes the environment but also attract pest such as rats, crows, flies and others, to create health-hazard to the nearby residents. The main objective of this study is to determine the viability of conducting small scale vermicomposting in order to divert the organic portion from the household waste stream. This study was aimed to find the most appropriate setup to conduct small scale vermicomposting suitable for households as a sustainable practice.

\section{MATERIALS AND METHODS}

The study involved the analysis of waste composition from household. Wastes were collected from 350 households from Selangor rural, sub-urban and urbans residents. The waste collected were sorted into organic, paper, plastic, metal, and others, and weighed to determine the percentage of each waste group. The results would indicate the possibility of implementing vermicomposting system as an alternative to landfill disposal. The experimental set-up includes the usage of plastic bucket for $\mathrm{T} 1$ and ceramic flower pots for T2 and T3. The experimental setup for each trial is shown in Figures 1-3. The function of each material used is detailed in Table 1.

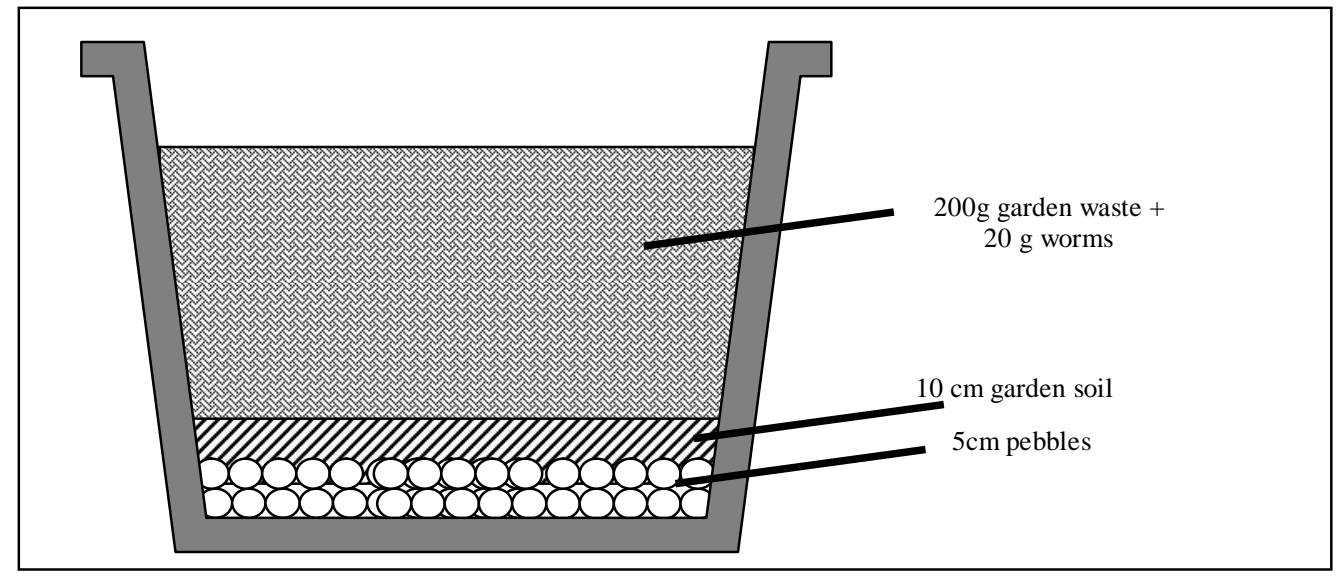

Figure 1. Vermicomposting experimental set-up for System T1

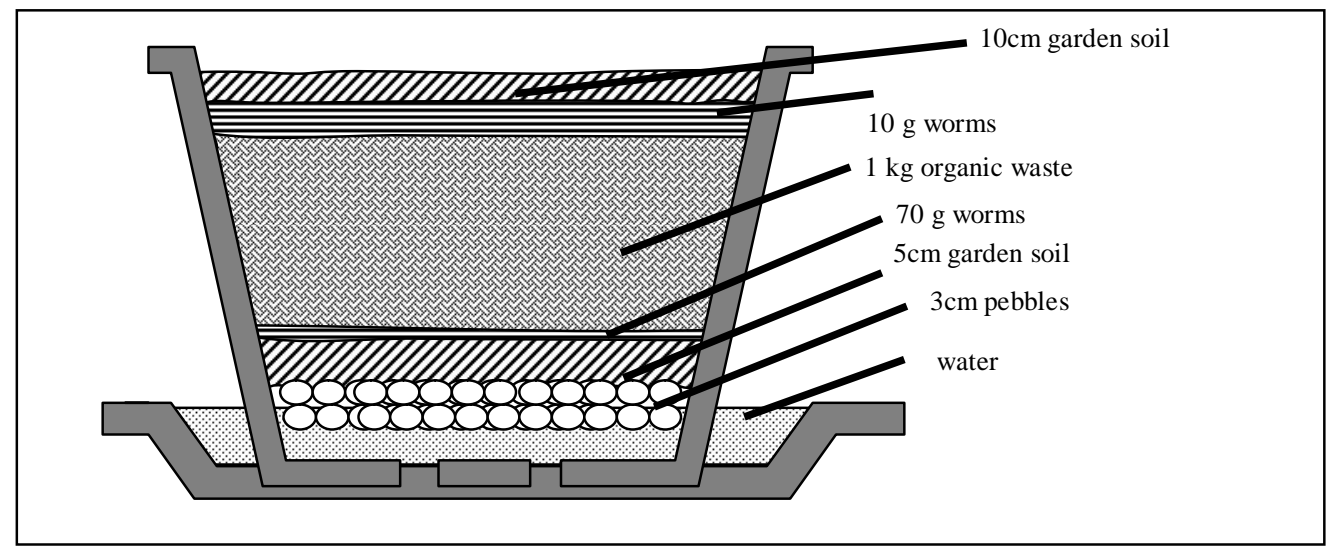

Figure 2. Vermicomposting experimental set-up for System T2 




Figure 3. Vermicomposting experimental set-up for System T3.

Table 1. Detailed function of each material in the vermicomposting set-up.

\begin{tabular}{|c|c|c|}
\hline Material & Used in set-up & Function \\
\hline Pebbles & System T1, T2 and T3 & $\begin{array}{l}\text { To act as drainage material to collect excess water from the } \\
\text { system }\end{array}$ \\
\hline $\begin{array}{l}\text { Garden soil } \\
\text { (bottom) }\end{array}$ & System T1, T2 and T3 & $\begin{array}{l}\text { To provide bedding material for worms prior to complete } \\
\text { adaptation to new system }\end{array}$ \\
\hline $\begin{array}{l}\text { Garden soil } \\
\text { (top) }\end{array}$ & System T2 and T3 & $\begin{array}{l}\text { To cover worms and waste materials, to reduce light } \\
\text { penetration and prevent offensive odour from escaping the } \\
\text { system }\end{array}$ \\
\hline $\begin{array}{l}\text { Bottom plate } \\
\text { with water }\end{array}$ & System T2 and T3 & $\begin{array}{l}\text { To trap worms that escape from the opening of the flower pot } \\
\text { base. }\end{array}$ \\
\hline $\begin{array}{l}\text { Cover plate } \\
\text { (top) }\end{array}$ & System T2 and T3 & $\begin{array}{l}\text { To prevent worms from getting preyed, to avoid insect from } \\
\text { getting into the system, to totally remove the source of light }\end{array}$ \\
\hline
\end{tabular}

Organic waste used in the experiment was mainly kitchen waste $(67 \%)$ with $33 \%$ grass clippings, goat manure, garden soil or vermicompost from earlier trials.

For each set-up, approximately $80 \mathrm{~g}$ of Eisenia foetida locally obtained were introduced. The experiment was allowed to take place for five weeks before the final products were analyzed. Physical and chemical analyses were conducted to determine the best combination.

\section{RESULTS AND DISCUSSION}

Waste generators from the 350 houses studied consisted of $65 \%$ middle income group, $24 \%$ high income group and $11 \%$ low income group. The studies indicated that approximately $55 \%$ of the
MSW consisted of organic portion, followed by plastic $(19 \%)$ and paper $(13 \%)$. The high organic component in the waste was due to the lack of bioremediation practice among the households to divert these putrescible wastes. Similar results were obtained from previous studies where most households lack composting practice which resulted with high percentage of organic component being present in the waste $[19,20]$. The average composition of MSW generated by the households in Selangor is shown in Figure 4.

The organic component featured in Figure 4 consisted of food waste $(41 \%)$, garden waste $(12.3 \%)$ and other organic waste $(1.76 \%)$. The implementation of vermicomposting would reduce at least $40 \%$ of waste from being disposed into landfills. 


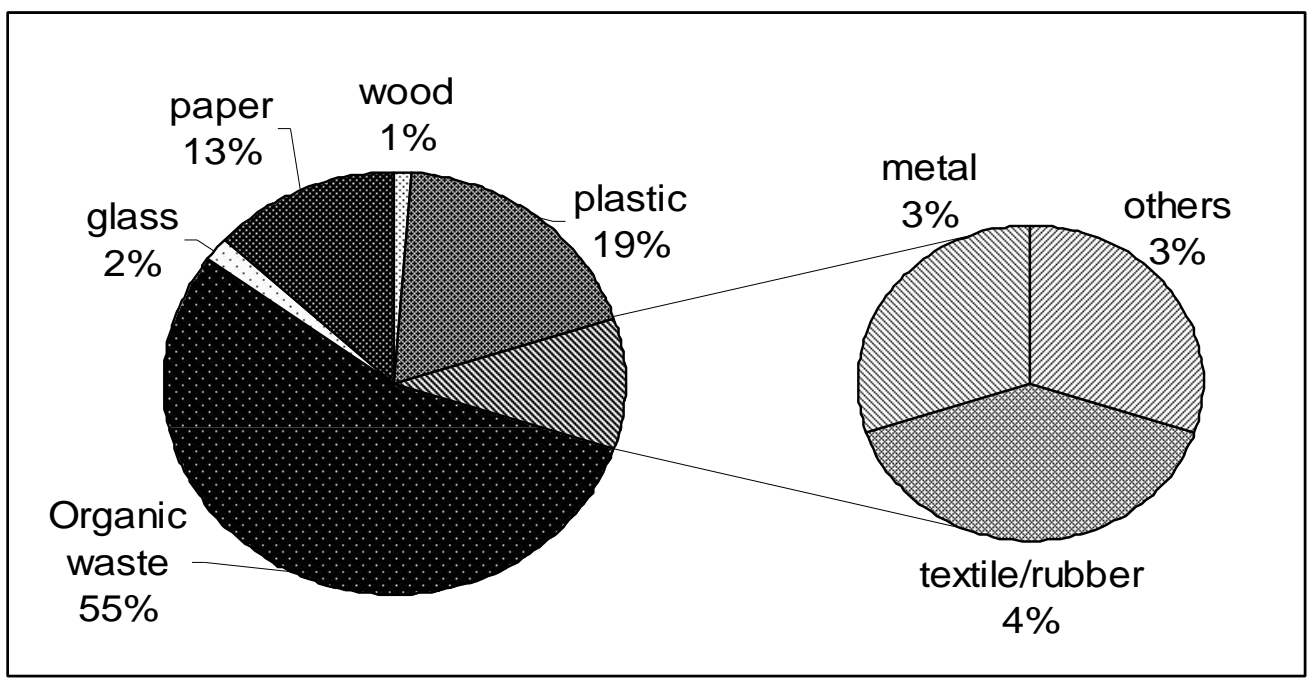

Figure 4. Average composition of domestic waste in Selangor

Vermicomposting in System T1 was relatively slow. Plastic bucket used was not conducive for vermicomposting and the lack of holes resulted with excess fluid being collected at the bottom of the bucket. However, the presence of pebbles helped to drain the system from excess moisture. This system required constant watering since the top layer is often dry. Therefore, approximately $10 \mathrm{ml}$ of water were sprinkled every other day. Mixing and turning was avoided to avoid disrupting the existing system. The process of composting was very slow and was completed after 90 days. The main factor contributing to the time-consuming system was raw material used i.e. garden waste which mainly consisted of dried leaves. The lignin and cellulose content of the leaves would require more ingestions by the worm to break it down to simpler structures [21]. Another set-back of this system was the problem of worms coming out from the bucket particularly when the moisture at the bottom layer was too high (more than 50\%). To avoid worms from escaping the system, constant monitoring is crucial. Therefore the set-up was found to be inconvenient for household application since it required a long time period (approximately 3 months) and constant monitoring (worms coming out of container).

System T2 was set up using ceramic flower pots with a plate of water underneath to prevent worms from escaping the system. The water not only managed to keep adult worms from escaping but also helped to accumulate the juveniles when they were flushed during the watering of the system. Main material used for the trial was kitchen waste with various combinations. A thin layer of top soil $(5 \mathrm{~cm})$ was applied to cover the organic waste and curb odour problem. The vermicomposting process completed after approximately 4 weeks with $\mathrm{pH}$ ranging from $\mathrm{pH}$ 4.9-6.4 and nitrate content 1-2.5\%. The low $\mathrm{pH}$ value recorded was probably due to the generation of organic acids [22]. However, this system was also not very convenient since it allows various types of insects to breed due to the presence of food waste. Among the main pests were larvae of beetles most likely from genus Cephaloleia. The larvae that look like Maybeetles larvae compete for food. The products also contained large amount of faeces generated by the insect larvae.

System T3 was an improved System T2 set-up where the vermicomposting systems were covered with ceramic plate to prevent the invasion of external insects particularly beetles and flies. The T3 set-ups were allowed to continue for 4 weeks without disturbance except watering. Due to covering of the system, minimum watering is required as evaporated moisture was collected under the cover and driped back into the system. No evidence of pest namely insect was visible in the vermicomposting system. The final products were more homogenous with soil like texture. The analysis conducted is depicted in Table 2. 
Table 2. Analysis of the vermicompost generated in System T3.

\begin{tabular}{lccccccc}
\hline Combination & $\begin{array}{l}\text { Final } \\
\text { pH }\end{array}$ & $\begin{array}{l}\text { Water } \\
\text { holding } \\
\text { capacity (\%) }\end{array}$ & $\begin{array}{l}\text { Total } \\
\text { organic } \\
\text { carbon }(\%)\end{array}$ & $\begin{array}{l}\text { Nitrate } \\
(\mathbf{m g} / \mathbf{k g})\end{array}$ & $\begin{array}{l}\text { Phosphate } \\
(\mathbf{m g} / \mathbf{k g})\end{array}$ & $\begin{array}{l}\text { Total } \\
\text { Potassium } \\
(\mathbf{m g} / \mathbf{k g})\end{array}$ & N:P:K \\
\hline 100\% Kitchen & 5.8 & 77.9 & 12.7 & 46.5 & 21.5 & 18.4 & $1: 1: 1$ \\
$\begin{array}{l}\text { Waste (KW) } \\
\text { 67\% KW + 33\% }\end{array}$ & 6.5 & 65.2 & 13.2 & 18.3 & 53.34 & 9.7 & $1: 3: 1$ \\
$\begin{array}{l}\text { Grass Clippings } \\
\text { 67\% KW + 33\% }\end{array}$ & 7.6 & 76.3 & 12.4 & 26.2 & 321.4 & 24.8 & $1: 12: 1$ \\
$\begin{array}{l}\text { Goat Manure } \\
\text { 67\% KW + 33\% }\end{array}$ & 6.5 & 78.6 & 12.2 & 27.44 & 33.17 & 19.1 & $1: 1: 1$ \\
$\begin{array}{l}\text { Vermicompost } \\
\text { 67\% KW + 33\% } \\
\text { Garden Soil }\end{array}$ & 7.1 & 74.3 & 11.1 & 6.5 & 65.8 & 8.8 & $1: 10: 1$ \\
\hline
\end{tabular}

The combination of $67 \%$ kitchen waste and $33 \%$ vermicompost was the fastest to complete (21 days). This is due to the utilization of vermicompost which consist mainly of the worms casting. It may have created a more suitable environment for the worms that the adaptation period was shortened and degradation was faster [23]. It was followed by the combination of goat manure and garden soil where degradation process completed after 24 days and 26 days, respectively. The factor which expedited the degradation was the short adaptation period resulting from the raw material used. This is so since the worms were collected from a goat farm.

Kitchen waste without any additives was the slowest to degrade since it contained various materials which were unfavorable factor to worms including oil, spices and others. With additives, this unfavourable has lesser effects as a result to reaction of kitchen waste and the additives. It was also observed that inclusion of certain citrus fruits hindered the degradation of the waste by the worms and eventually killed them. The water holding capacity of the vermicompost ranged from approximately $65 \%$ to $79 \%$ indicating approximately $12-17 \%$ increase from the value at the initial stage. On the other hand, total organic carbon increased 9-14\% (wt) from the initial value where final products have a range of $11 \%$ to $13 \%$. Analysis of the metal elements in the final products is shown in Table 3 .

Table 3. Heavy metals in vermicompost

\begin{tabular}{lcccccc}
\hline Samples & $\begin{array}{l}\mathbf{C r} \\
(\mathbf{m g} / \mathbf{k g})\end{array}$ & $\begin{array}{l}\mathbf{C u} \\
(\mathbf{m g} / \mathbf{k g})\end{array}$ & $\begin{array}{l}\mathbf{C d} \\
(\mathbf{m g} / \mathbf{k g})\end{array}$ & $\begin{array}{l}\mathbf{N i} \\
(\mathbf{m g} / \mathbf{k g})\end{array}$ & $\begin{array}{l}\mathbf{Z n} \\
(\mathbf{m g} / \mathbf{k g})\end{array}$ & $\mathbf{P b}(\mathbf{m g} / \mathbf{k g})$ \\
\hline 100\% Kitchen Waste (KW) & nd & 0.01 & nd & 10.03 & 5.66 & nd \\
67\% KW + 33\% Grass Clippings & nd & 0.02 & nd & 10.89 & 17.28 & nd \\
67\% KW + 33\% Goat Manure & nd & 0.01 & nd & 9.45 & 16.9 & nd \\
67\% KW + 33\% Vermicompost & nd & 0.04 & nd & 7.33 & 42.93 & nd \\
67\% KW + 33\% Garden Soil & nd & 0.02 & nd & 10.74 & 22.07 & nd \\
EU limit range* & $70-200$ & $70-600$ & $0.7-10$ & $20-200$ & $70-1000$ & $210-4000$ \\
USA biosolid limit* & 1200 & 1500 & 39 & 420 & 300 & 2800 \\
\hline
\end{tabular}

Note: $\mathrm{nd}=$ not detected; $*$ [24]

Concentration of $\mathrm{Pb}, \mathrm{Cr}$ and $\mathrm{Cd}$ were below the detection limit while others indicated approximately $32-45 \%$ increase from the initial raw materials. All of the concerned elements were within the acceptable range of both EU limit and USA Biosolid limit.
Presence of heavy metal concentration in vermicompost will have detrimental effects upon plant application $[25,26]$. Though no regular pattern is observed in final vermicomposts in relation to initial concentration, the increase in heavy metal content could probably be attributed to the massive 
degradation process of the raw materials and the mineralization process. The increase of heavy metal content in vermicompost was also recorded by findings on various types of raw materials [27, 28].

\section{DISCUSSION}

Results indicated that household putrescible waste can easily undergo vermicomposting. However, factors such as high acidity and presence of certain materials in the waste can be a disadvantage to this process. The $\mathrm{pH}$ reduction is mainly contributed by the generation of organic acid such as fulvic and humic acids [22, 29, 30, 31]. Experimental set-up with the layering system proved to be the most suitable method of conducting small scale vermicomposting. The layering set-up prevents worms from escaping the system and allows the gathering of the offspring in a safe environment. Different combinations of organic mixture resulted with different rate of vermicomposting. The fastest degradation was the combination of kitchen waste with vermicompost, which was completed within 3 weeks. It was so as it provides the most suitable environment for the worms to flourish in addition to the availability of less complex components.

\section{CONCLUSIONS}

Vermicomposting of organic components found in the MSW stream can be accomplished by taking into consideration some crucial factors such as acidity and presence of hindering factors. The best experimental set-up is the layering system of organic waste with soil which should cater the suitable environment for the worms as well as not allowing intrusion of other competitive organisms. The set-up is applicable to household vermicomposting since it is fast and convenient with minimal monitoring.

\section{REFERENCES}

1. Odum, H.T and Odum, E.C. (2006). The prosperous way down. Energy 31(1): 21-32

2. Fauziah S.H., Noorazamimah Aiza, A. and Agamuthu, P. (2007). Closure and Post-closure of Landfills in Malaysia - Case Studies. Proceedings of ISWA/WMRAS World Congress 2007, Amsterdam, The Netherlands, pp. 1-9.

3. Wagner, T and Arnold, P. (2008). A new model for solid waste management: an analysis of the Nova Scotia MSW strategy. Journal of Cleaner Production 16(4): 410-421.

4. Agamuthu P. and Fauziah S.H. (2008). Waste management technologies in Malaysia: The future prospect. Proceeding of iCAST Future Challenge: An integrated approach towards Science and Technology for Sustainable development, Pahang, Malaysia, pp. 1-3.

5. Agamuthu P. and Fauziah S.H. (2007). Recent Issues in Solid Waste Management in Malaysia: The Solid Waste Bill, 2007. Proceedings of The $3^{\text {rd }}$ Expert Meeting on Solid Waste Management in Asia and Pacific Islands, Okayama, Japan, pp. S1-3-1 -S1-3-6.

6. Gómez Palacios, J.M., de Apodaca, A. R., Rebollo, C. and Azcárate, J. (2002). European policy on biodegradable waste: a management perspective. Water Science Technology 46: 311318.

7. Agamuthu, P. (2001). Solid Waste: Principle and Management. University of Malaya Press.

8. Hellweg, S., Hofstetter, T.B. and Hungerbühler K. (2001). Modeling waste incineration for life cycle inventory analysis in Switzerland. Environmental Model Assessment 6: 219-35.

9. Gajdoš, R. (1998). Bioconversion of organic waste by the year 2010: to recycle elements and save energy. Resources, Conservation and Recycling 23(1-2): 67-86

10. Lynch, D.H., Voroney, R.P. and Warman, P.R. (2006). Use of $13 \mathrm{C}$ and $15 \mathrm{~N}$ natural abundance techniques to characterize carbon and nitrogen dynamics in composting and in compostamended soils. Soil Biology and Biochemistry 38(1): 103-114.

11. Jakobsen, S.T. (1995). Aerobic decomposition of organic wastes 2. Value of compost as a fertilizer. Resources, Conservation and Recycling 13(1): 57-71

12. Mochty, F. (1996). Regulations in the field of biowaste collection and treatment in Austria. In: Management of Urban Degradable Waste. (ed. Hansen, J. A.ISWA) James \& James (Science Publishers). United Kingdom. 
13. Schenkel, W. (1996). Conceptual Approach in Legislation and Regulation Concerning Organic Wastes from Cities. In: Management of Urban Degradable Waste. (ed. Hansen, J. A., ISWA) James \& James (Science Publishers). United Kingdom.

14. Mohee, R. and Mudhoo, A. (2005). Analysis of the physical properties of an in-vessel composting matrix. Powder Technology 155(1): 92-99

15. Tripathi G. and Bhardwaj, P. (2004). Comparative studies on biomass production, life cycle and composting efficiency of Eisenia fetida (Savigny) and Lampito mauritii (Kinberg). Bioresource Technology 92: 275-283.

16. Suthar, S. (2006). Potential Utilization of guar gum industrial waste in vermicompost production. Bioresource Technology 97(18): 2474-2477.

17. Agamuthu, P. (2004) (Third Edition). Utilization and Management of Agricultural and Agro-industrial Waste. University of the West Indies, Mona, Jamaica.145 pp. (ISBN 983-208529-2).

18. Yardim, E.N., Arancon, N.Q., Edwards, C.A., Oliver, T.J. and Byrne, R.J. (2006). Suppression of tomato (Manduca quinquemaculata) and cucumber bettle (Acalymma vittatum and Diabotrica undecimpunctata) population and damage by vermicomposts. Pedobiologia 50: 23-29.

19. Fauziah, S.H. and Agamuthu, P. (2007) SWPlan software application for Malaysian municipal solid waste management. Malaysian Journal of Science 26 (1): 17-22.

20. Kathirvale, S., Muhd Noor, M. Y., Kamaruzzaman, S., Abdul Halim, S. (2004). Energy potential from municipal solid waste in Malaysia. Renewable Energy 29(4), pp 559-567.

21. Manna, M. C., Jha, S., Ghosh, P. K. and Acharya, C. L. (2003). Comparative efficacy of three epigeic earthworms under different deciduous forest litters decomposition. Bioresource Technology 88(3): 197-206.

22. M.P. Raut, S.P.M. Prince William, J.K. Bhattacharyya, T. Chakrabarti, S. Devotta (2008). Microbial dynamics and enzyme activities during rapid composting of municipal solid waste - A compost maturity analysis perspective. Bioresource Technology 99(14): 6512-6519.

23. Gunadi, B. and Edwards, C.A. (2003). The effect of multiple applications of different organic wastes on the growth, fecundity and survival of Eisenia fetida. Pedobiologia 47: 321-330.

24. Gupta, R. and Garg, V.K. (2008) Stabilization of primary sewage sludge during vermicomposting. Journal of Hazardous Materials 153(3): 1023-1030.

25. A.J. Whittle and A.J. Dyson (2002) The fate of heavy metals in green composting. Environmentalist 22:13-21.

26. Yadav, A. and Garg, V.K. (2009) Feasibility of nutrient recovery from industrial sludge by vermicompsoting technology. Journal of Hazardous Materials. 168:262-268.

27. Deolalikar, A.V., Mitra, A., Bhattacharyee, S. and Chakraborty, S. (2005). Effect of vermicomposting process on metal content of paper mill solid waste. Journal of Environmental Science and Engineering 47: 81-84.

28. Elvira, C., Sampedro, L., Benitez E. and Nogales, R. (1998). Vermicomposting of sludges from paper mill and dairy industries with Eisenia andrei: a pilot scale study. Bioresourse Technology 63: 205-211.

29. Abouelwafa, R., Amir, S., Souabi, S., Winterton, P., Ndira, V., Revel, J. and Hafidi, M. (2008). The fulvic acid fraction as it changes in the mature phase of vegetable oil-mill sludge and domestic waste composting. Bioresource Technology 99(14): 6112-6118.

30. Cayuela, M.L., Mondini, C., Sánchez-Monedero, M.A.. and Roig, A (2008). Chemical properties and hydrolytic enzyme activities for the characterisation of two-phase olive mill wastes composting. Bioresource Technology 99(10): 4255-4262.

31. Amir, S., Hafidi, M., Lemee, L., Merlina, G., Guiresse, M., Pinelli, E., Revel, J.-C., Bailly, J.R. and Ambles, A. (2006). Structural characterization of humic acids, extracted from sewage sludge during composting, by thermochemolysis-gas chromatography-mass spectrometry. Process Biochemistry 41(2): 410422. 